\title{
Surveillance of Giardia and Cryptosporidium in sewage from an urban area in Brazil
}

\author{
Monitoramento de Giardia e Cryptosporidium em esgoto de uma área urbana no Brasil \\ Felippe Danyel Cardoso Martins'; Winni Alves Ladeia ${ }^{1}$; Roberta dos Santos Toledoº ; João Luis Garcia'; \\ Italmar Teodorico Navarro ${ }^{1}$; Roberta Lemos Freire ${ }^{1 *}$ (1)
}

\begin{abstract}
${ }^{1}$ Departamento de Medicina Veterinária Preventiva, Universidade Estadual de Londrina - UEL, Londrina, PR, Brasil
${ }^{2}$ Faculdade Integrado de Campo Mourão, Campo Mourão, PR, Brasil
\end{abstract}

Received December 22, 2018

Accepted May 01, 2019

\begin{abstract}
Cryptosporidium and Giardia are protozoan parasites that cause diarrhea in humans and animals. Molecular characterization of these pathogens in sewage may provide insight on their occurrence and prevalence in Brazil. This study aimed to investigate the presence of Giardia and Cryptosporidium in raw and treated sewage from Londrina, Paraná, Brazil. Samples were collected every two weeks during a year. Samples were concentrated, then DNA was extracted and subjected to a nested PCR targeting the Giardia 18S rRNA gene and the Cryptosporidium 18S rRNA gene. Species of Cryptosporidium were characterized by restriction fragment length polymorphism (RFLP). All raw sewage and $76 \%$ of the treated sewage were positive for Giardia; $84 \%$ of raw sewage samples and $8 \%$ of treated sewage were positive for Cryptosporidium. C. muris, C. hominis, C. baileyi, C. parvum and C. suis were detected in 100\%, 19\%, 9\%, 9\% and 4\% of raw sewage, respectively. C. muris was the only species found in treated sewage. Multiple species of Cryptosporidium were present in $19.04 \%$ of the raw sewage. Treated sewage water can pose a threat to human health. The speciation of Cryptosporidium revealed the presence of non-common zoonotic species as C. suis and C. muris.
\end{abstract}

Keywords: Neglected diseases, diarrhea, environmental pollution, PCR-RFLP, raw sewage, monitoring.

\section{Resumo}

Cryptosporidium e Giardia são protozoários causadores de diarreia em animais e humanos. A caracterização molecular destes protozoários em esgoto pode prover dados ainda desconhecidos da ocorrência de espécies. O objetivo do presente estudo foi monitorar a ocorrência de Giardia e espécies de Cryptosporidium em esgoto bruto e tratado, em uma estação de tratamento de esgoto (ETE) de Londrina, Paraná. Amostras de esgoto bruto e tratado foram coletadas no período de um ano, com periodicidade quinzenal. A ocorrência destes protozoários foi caracterizada por meio de concentração das amostras e posterior extração de DNA seguida de nested-PCR para amplificação de fragmentos dos genes 18S rRNA de Giardia e 18S rRNA de Cryptosporidium. A caracterizaçáo das espécies de Cryptosporidium foi realizada por meio de análise por polimorfismo de comprimento do fragmento de restrição (RFLP) dos produtos obtidos. Foram coletadas no total 25 amostras de cada, esgoto bruto e esgoto tratado. Para Giardia, todas as amostras de esgoto bruto e $76 \%$ das de esgoto tratado foram positivas. Cryptosporidium esteve presente em $84 \%$ das amostras de esgoto bruto e em $8 \%$ do tratado. No esgoto tratado foi encontrado apenas $C$. muris, já nas amostras de esgoto bruto foram encontradas cinco espécies: C. muris, C. hominis, C. baileyi, C. suis e C. parvum em 100\%, 19\%, 9\%, 9\% e 4\%, respectivamente. A presença de espécies mistas foi observada em 19,04\% das amostras. A presença de Giardia e Cryptosporidium em esgoto tratado pode pôr em risco a saúde humana. A discriminaçáo de espécies de Cryptosporidium revelou a presença de espécies zoonóticas incomuns como C. suis e C. muris.

Palavras-chave: Doenças negligenciadas, diarreia, contaminação ambiental, PCR-RFLP, esgoto bruto, monitoramento.

*Corresponding Author: Roberta Lemos Freire. Departamento de Medicina Veterinária Preventiva, Universidade Estadual de Londrina - UEL, Rodovia Celso Garcia Cid, Km 380, Campus Universitário, CEP 86057-970, Londrina, PR, Brasil. E-mail: rlfreire@uel.br 


\section{Introduction}

Cryptosporidium and Giardia are protozoan parasites that cause anthroponotic or zoonotic diarrheal disease which can be opportunistic or affect healthy, immunocompetent individuals. Cryptosporidiosis and giardiasis were included in a list of neglected diseases compiled by the World Health Organization (WHO), and are considered the main causes of outbreaks of waterborne protozoan disease (EFSTRATIOU et al., 2017; RYAN et al., 2014; RYAN \& CACCIÒ, 2013; SAVIOLI et al., 2006).

In Brazil, these organisms have been found in a variety of samples from different sources including raw water, spring water, bottled water, treated sewage, raw sewage, sewage sludge, and vegetables (ALMEIDA et al., 2015; BONATTI \& FRANCO, 2016; BRANCO et al., 2012; FRANCO \& CANTUSIO, 2002; SANTOS et al., 2011; TIYO et al., 2015).

Genus Cryptosporidium comprises 38 species, of these Cryptosporidium parvum and Cryptosporidium meleagridis are the most frequent species associated with zoonotic transmission (FENG et al., 2018). Regarding Giardia, eight species have been described, out of then the species complex Giardia duodenalis is the one commonly described in mammals including humans, this species complex comprise eight assemblages (RYAN et al., 2019). Molecular data on the distribution of species, genotypes, and genetic assemblages of these protozoan parasites in Brazil is largely lacking in the literature, mainly due to negligence, technical difficulties, and the high cost of equipment and laboratory tests. Such data is essential to investigating the epidemiological trends, dynamics of transmission, disease patterns, and public health risks (FRANCO et al., 2012).

Molecular characterization of these pathogens in clinical samples from different hosts should be performed as it provides important taxonomic and biological data. This information can further our understanding of the epidemiology and prevalence of protozoan species or assemblages so, preventive measures and control strategies should be put into action based on these surveillance findings. Nevertheless, most of the molecular studies on Cryptosporidium and Giardia that have been carried out in Brazil analyzed animal samples (COUTO et al., 2014; DURIGAN et al., 2014; MEIRELES, 2010; NAKAMURA et al., 2009; SILVA et al., 2012, 2013).

In Brazil, cases of cryptosporidiosis due to $C$. hominis and less frequently $C$. parvum have been described in children and in immunosuppressed adults (ROLANDO et al., 2012). There are also reports, in low frequency, of $C$. meleagridis, $C$. felis, and C. canis infection in immunocompromised patients (ARAÚJO et al., 2008). Molecular characterization of Giardia in humans has mostly focused on demonstrating the occurrence of a zoonotic cycle, subassemblages of Giardia duodenalis frequently detected in the country are AI, AII, and BIV (COLLI et al., 2015; DURIGAN et al., 2014).

The detection of Giardia genetic assemblages and Cryptosporidium species in raw sewage samples has been used as a molecular epidemiology tool to monitor the occurrence of these protozoan parasites in the environment and to understand disease transmission dynamics (FENG et al., 2009; PLUTZER et al.,
2008; ULLOA-STANOJLOVIĆ et al., 2016). Considering the environment, the characterization of these pathogens in sewage may provide insight on their occurrence and prevalence in areas without a host-based surveillance (SPANAKOS et al., 2015; XIAO et al., 2001). Nevertheless, methods able to elucidate species mixtures within a sample are necessary as the standard PCR follow sequencing only diagnostic the most abundant species (ZAHEDI et al., 2017).

The present study consisted of a one-year survey that was conducted with the aim of monitoring the occurrence of Giardia and Cryptosporidium species in raw and treated sewage samples from a wastewater treatment plant (WWTP).

\section{Materials and Methods}

\section{Description of the study area}

The study was conducted in city of Londrina ( $23^{\circ} 18^{\prime} 36^{\prime \prime}$ S $\left.51^{\circ} 09^{\prime \prime} 46^{\prime \prime} \mathrm{W}\right)$ which is located in the north of the State of Paraná (PR), south Brazil. Londrina is the second largest city in the State of Paraná with a total population of 548.240, and the fourth largest city in southern Brazil. The metropolitan area has more than 1 million people, and an HDI (Human Development Index) of 0.778 . Regarding basic sanitation, $89 \%$ of consumed water is treated as sewage and all sewage produced is treated. There is rainfall throughout the year. The average annual rainfall is $1429 \mathrm{~mm}$ (IBGE, 2015)

\section{Characteristics of the Wastewater Treatment Plant (WWTP)}

The WWTP selected is in charge of the sewage treatment in a geographic area with approximately 245.000 inhabitants. This WWTP receives an average of $3.4 \times 10^{3} \mathrm{~m}^{3}$ of wastewater per day, performs preliminary, primary, and secondary sewage treatments consisted of railing, sand trap, primary decanter, fluidized sludge anaerobic reactors, and trickling filter, with a hydraulic retention time of 18 hours. Effluent flows into the Cambezinho stream and is categorized as class II according to the decree 357/05 of the Environment National Council (CONAMA) which categorizes waterbodies in five different classes (special, I, II, III, IV) according to water quality.

\section{Sample collection}

Samples were collected every two weeks between December 2014 and November 2015. In every sample collection day between 8:00 am and 9:00 am, $1 \mathrm{~L}$ of raw sewage was collected after the sand trap, and $2 \mathrm{~L}$ of treated sewage was collected before the runoff in Cambezinho stream, Londrina, PR, Brazil, both using a plastic jar as a sampler. A total of 25 samples of raw sewage, and 25 samples of treated sewage were collected. Samples were stored in plastic bottles which were previously sanitized and rinsed with Tween ${ }^{\circledR} 800.1 \%$. Specimens were transported to the laboratory in isothermal boxes and processed within 24 hours after arrival. 


\section{Sample Concentration}

We concentrated $500 \mathrm{~mL}$ of raw sewage by centrifugation (SANTOS et al., 2011). Briefly, each sample was placed in a $50 \mathrm{~mL}$ tube containing $5 \mathrm{~mL}$ of Tween ${ }^{\circledR} 801 \%(\mathrm{v} / \mathrm{v})$, homogenized, and subjected to centrifugation at $1500 \mathrm{xg}$ for 15 minutes in a swing rotor with no brake. The supernatant was removed with a sterile disposable pipette. The sediment was resuspended in $0.1 \%$ Tween ${ }^{\circledR} 80(\mathrm{v} / \mathrm{v})$, packed in a $50 \mathrm{~mL}$ tube, and further subjected to centrifugation as described above. Again, the sediment was resuspended in Tween ${ }^{\circledR} 800.1 \%(2-4 \mathrm{~mL})$ and stored at $4^{\circ} \mathrm{C}$ with $50 \mathrm{ng}$ of gentamicin and streptomycin and $0.02 \mathrm{U}$ penicillin $/ \mathrm{mL}$ until DNA extraction.

An aliquot of $1.2 \mathrm{~L}$ from each sample of treated sewage was concentrated by filtration and by centrifugation as well (SANTOS et al., 2011). Briefly, samples were filtered through cellulose ester membranes (pore diameter: $1.2 \mu \mathrm{m}$; filter support: $47 \mathrm{~mm}$ diameter). Membranes were eluted in Tween ${ }^{\circledR} 80$ 0.1\% $(\mathrm{v} / \mathrm{v})$ by scraping, and the eluted membranes were centrifuged at $1500 \mathrm{x} \mathrm{g}$ for 15 minutes. The sediment was resuspended in Tween $^{\circledR} 800.1 \%(\mathrm{v} / \mathrm{v})$ and centrifuged as mentioned above. The final sediment was resuspended in Tween ${ }^{\circledR} 800.1 \%$ (1-2mL) and stored at $4^{\circ} \mathrm{C}$ with $50 \mathrm{ng}$ gentamicin and streptomycin and $0.02 \mathrm{U}$ penicillin/mL until DNA extraction.

\section{DNA extraction}

DNA was extracted from $200 \mu \mathrm{L}$ of sewage concentrate using the NucleoSpin Tissue ${ }^{\circledR}$ (Macherey-Nagel) commercial kit according to the manufacturer's protocol. A few modifications were introduced in the original protocol and includes 3 freeze/thaw cycles prior to the lysis step in order to promote increased rupture of cysts and oocysts (WELLS et al., 2015).

\section{Polymerase Chain Reaction (PCR) for Giardia}

A triplicate nested PCR was performed to amplify a $18 \mathrm{~S}$ rRNA gene fragment of Giardia (APPELBEE et al., 2003; HOPKINS et al., 1997). The reaction consisted of $1 X$ PCR buffer; $200 \mu \mathrm{M}$ of each dNTP; $1.5 \mathrm{mM} \mathrm{MgCl} ; 200 \mathrm{nM}$ of each primer; $5 \%$ dimethyl sulfoxide (DMSO); 1.25 U Platinum ${ }^{\circledR}$ Taq DNA Polymerase (Invitrogen); $1.5 \mu \mathrm{L}$ of DNA, and ultrapure water to reach a volume of $25 \mu \mathrm{L}$.

The product of the first round PCR was diluted in $50 \mu \mathrm{L}$ of ultrapure water for the second round PCR. The amplification step consisted of the following cycles: 5 minutes at $95^{\circ} \mathrm{C}$ followed by 35 cycles of 45 seconds at $94^{\circ} \mathrm{C}, 45$ seconds at $58^{\circ} \mathrm{C}$ in the first reaction, $55^{\circ} \mathrm{C}$ in the second reaction, 60 seconds at $72^{\circ} \mathrm{C}$, and 5 minutes at $72{ }^{\circ} \mathrm{C}$. Ultrapure water was used as negative control and DNA of Giardia duodenalis assemblage C obtained from a dog as positive control. PCR products were submitted to electrophoresis in $1.5 \%$ agarose gel stained with SYBR Safe ${ }^{\circledR}$, after the gels were photo documented.

\section{Polymerase Chain Reaction (PCR) for Cryptosporidium}

A triplicate nested-PCR was carried out to detect a Cryptosporidium $18 \mathrm{~S}$ rRNA gene fragment ranging in length from 823 to $840 \mathrm{bp}$ (XIAO et al., 2001). The reaction consisted of $1 \mathrm{X}$ PCR buffer; $200 \mu \mathrm{M}$ of each dNTP; $2.5 \mathrm{mM}$ of $\mathrm{MgCl}_{2} ; 400 \mathrm{nM}$ of each primer; $1.25 \mathrm{U}$ of Platinum ${ }^{\circledR}$ Taq DNA Polymerase (Invitrogen); $200 \mathrm{ng} / \mu \mathrm{l}$ nonacetylated bovine serum albumin (BSA); $2.0 \mu \mathrm{L}$ of extracted DNA, and ultrapure water to a final volume of $25 \mu \mathrm{L}$. The product of the first reaction was diluted with $50 \mu \mathrm{L}$ ultrapure water before the second PCR assembly.

The amplification steps for both reactions were: 5 minutes at $95^{\circ} \mathrm{C}$; followed by 35 cycles of 45 s at $94^{\circ} \mathrm{C}$; 45 s at $55^{\circ} \mathrm{C}$; 60 s at $72{ }^{\circ} \mathrm{C}$ and 5 minutes at $72{ }^{\circ} \mathrm{C}$. Ultrapure water was used as negative controls, and C. parvum DNA obtained from a calf was used as positive control. PCR products were subjected to $1.5 \%$ agarose gel electrophoresis. Gels were stained with SYBR Safe ${ }^{\circledR}$ and photographed.

\section{Discrimination of Cryptosporidium species by PCR-RFLP}

Second round PCR products that were positive for Cryptosporidium were subjected to restriction fragment length polymorphism (RFLP). The enzymes SspI, AseI, DdeI and Mboll were used for species discrimination (FENG et al., 2007; XIAO et al., 2001). Digestions were performed separately. Each digestion consisted of $1 \mathrm{X}$ Buffer $\mathrm{NEB}^{\circledR} ; 5 \mathrm{U}$ of enzyme (SspI and Mboll) or $3 \mathrm{U}$ (AseI and Ddel); $5 \mu \mathrm{L}$ of the second round PCR product, and ultrapure water up to $20 \mu \mathrm{L}$. Samples were incubated for 1 hour at $37^{\circ} \mathrm{C}$ and for 15 minutes at $65^{\circ} \mathrm{C}$. RFLP products were subjected to $2.5 \%$ agarose gel electrophoresis. Gels were stained with SYBR Safe ${ }^{\circledR}$ and photographed. Band patterns on the gels were compared with those from images available at Cryptodb (Heiges et al., 2006). In those cases, in which of co-infection was suspected, samples were compared with cleavage patterns generated by NebCutter v2.1 with reference sequences retrieved from GenBank database (accession: KT151526, GU254175, AF108864, EU331242 and DQ836341) (VINCZE et al., 2003).

\section{Results}

All raw sewage samples were positive for Giardia, and 84\% (21/25) were positive for Cryptosporidium. The prevalence of these two protozoan parasites was lower in treated sewage samples; 76\% (19/25) were positive for Giardia, and 8\% (2/25) for Cryptosporidium.

Giardia was more frequently found than Cryptosporidium in the raw sewage sample replicates, $88 \%(22 / 25)$ of the raw sewage samples were positive for Giardia in all three replicates and $12 \%$ $(3 / 25)$ in two replicates; $19 \%(4 / 21)$ of the raw sewage samples were positive for Cryptosporidium in all three replicates, 38\% (8/21) in two replicates, $42 \%(9 / 21)$ in one replicate. In treated sewage Giardia was detected in 26\% (5/19) of samples in all three replicates and 31\% (6/19) in two replicates, considering Cryptosporidium both positive samples had only one positive replicate. 
Table 1. Raw sewage samples with more than one species of Cryptosporidium identified by PCR-RFLP. Samples were collected bimonthly between December 2014 and November 2015 in a wastewater treatment plant (WWTP) in the city of Londrina, State of Paraná, Brazil.

\begin{tabular}{lcl}
\hline $\begin{array}{c}\text { Raw sewage } \\
\text { samples }\end{array}$ & $\begin{array}{c}\text { PCR-RFLP } \\
\text { replicates }\end{array}$ & \multicolumn{1}{c}{ Species identification } \\
\hline RS6 & 1 & C. muris \\
& 2 & C. muris, C. hominis \\
RS12 & 3 & C. muris, C. hominis \\
& 1 & C. muris, C. baileyi, C. suis, C. hominis \\
RS14 & 2 & C. baileyi, C. suis, C. hominis \\
& 1 & C. muris, C. hominis \\
& 2 & C. baileyi, C. suis, C. hominis \\
RS20 & 3 & C. baileyi, C. suis, C. hominis \\
& 1 & C. muris \\
& 2 & C. hominis, C. parvum \\
\hline
\end{tabular}

Identification of the species of Cryptosporidium was achieved by PCR-RFLP in all positive raw sewage and treated sewage samples. Five species of Cryptosporidium were found in raw sewage: $C$. muris, $C$. hominis, $C$. baileyi, $C$. suis, and $C$. parvum. A high frequency of $C$. muris was detected in these samples as all samples had the pattern for this species in at least one replicate, $C$. hominis was found in 19\% (4/21) of raw sewage samples. C. suis and C. baileyi were present in $9 \%(2 / 21)$ of these samples. We detected $C$. parvum in $4 \%(1 / 21)$ of raw sewage samples. Only $C$. muris was identified in treated sewage samples.

The presence of more than one species of Cryptosporidium in the same sample was observed in 19\% (4/21) of raw sewage specimens, and included different combinations of two or three species: C. muris/C. hominis; C. hominis/C. parvum; C. suis/C. baileyi/C. hominis, and C. suis/C. baileyi/C. hominis /C. muris.

In all samples in which more than one species of Cryptosporidium was detected, there was a difference in the number of species of this protozoan parasite found depending on the replicate. The result of a replicate of one sample was inconclusive, a large number of bands in the gel made the interpretation difficult and the specimen non-diagnostic. The results of the analysis of samples in which more than one species of Cryptosporidium was found in PCR replicates are summarized in Table 1.

\section{Discussion}

The present survey demonstrates the occurrence of Giardia and Cryptosporidium species in raw and treated sewage samples collected in a large city from south Brazil. Previously published studies have reported the presence, in Brazil and other countries, of these two protozoan parasites in sewage (LI et al., 2012; MONTEMAYOR et al., 2005; NGUYEN et al., 2016; ROBERTSON et al., 2000; SANTOS et al., 2011; ULLOA-STANOJLOVIĆ et al., 2016). However, few studies have been able to determine the species of Giardia and Cryptosporidium that are present within the samples examined. The methods used in these studies including direct immunofluorescence (DIF), PCR and sequencing, cannot discriminate species mixtures, considering the molecular assays also the organism's viability.

The presence of Giardia in all raw sewage samples tested suggests that this pathogen is endemic in this geographic area, nevertheless as the PCR is designed for genus diagnostic this high occurrence can't be attributed to a specific host. In the present study, the detection of Giardia in treated sewage that was being released into a creek highlights that water bodies that receive treated sewage should be monitored for protozoal contamination. This is especially important when these are used in agriculture or for consume by animals and humans, thus mitigation on parasite discharge should be performed (XIAO et al., 2018). The presence of Giardia in humans, dogs and vegetables in Brazil has been described and through genotyping of the Giardia isolates a correlation between them was established, negligence in the use of water sources for irrigation favored the perpetuation of the parasite's life cycle and maintenance of the disease in the population (COLLI et al., 2015).

Method used in this study for discrimination of Cryptosporidium species was primarily applied to environmental samples in raw sewage samples and treated sewage receptors rivers in the United States (XIAO et al., 2001). In this study, we obtained similar results mainly about the species found in raw sewage: $C$. muris, C. parvum and C. hominis. PCR-RFLP has been applied in raw sewage samples in China, they have also reported the presence of $C$. baileyi and C. suis, and in $15.87 \%$ of the positive samples there were multiple species (FENG et al., 2009).

The ability of the PCR-RFLP to discriminate species mixtures of Cryptosporidium in the same sample has been demonstrated, nevertheless, it may be difficult in some samples as many species of the parasite may be present resulting in extremely mixed patterns (RUECKER et al., 2005). This was seen in only one replicate of the present study. Limiting the target sequences before testing the samples by PCR-RFLP or by PCR amplification followed by sequencing, would help, however, these molecular assays require many replicates and may result yet in extremely mixed patterns or overlapping peaks in chromatograms and also lack of amplification due to random variations of the template (RUECKER et al., 2005, 2011; SPANAKOS et al., 2015). Next generation sequence is also a promising approach to better understand the diversity of Cryptosporidium species within a raw sewage sample, in Australia NGS revealed a huge diversity of species in raw sewage samples, nevertheless, this tool requires a highly technified staff and in most places is an expensive tool (ZAHEDI et al., 2017).

The presence of $C$. muris in all positive samples suggests contamination of the sewage system by rodent feces. Rodents are the main reservoir of $C$. muris, and these animals are known to be present in sewage collection system (SPANAKOS et al., 2015; THOMPSON \& ASH, 2016). In studies carried out in Europe and in the United States, researchers found C. muris in raw sewage samples and inferred that waters were contaminated by rodent feces (KHOUJA et al., 2010; SPANAKOS et al., 2015; XIAO et al., 2001). The finding of $C$. muris in treated sewage shows that this rodent pathogen occurs in wastewater treatment plants and indicates that other species of Cryptosporidium may be released into the environment posing a significant risk to public health. C. muris is described with low frequency in humans and mostly in immunosuppressed patients (CAMA et al., 2003) 
Experimental studies showed that $C$. muris can cause mild diarrhea in humans resulting in persistent and asymptomatic infection (CHAPPELL et al., 2015). Thus, C. muris could probably circulates in the population.

C. muris was present in all positive samples, this finding may suggest that this species is more abundant underestimating other species of Cryptosporidium present in the same geographic area. The presence of multiple species of Cryptosporidium in the same sample can results in the amplification by PCR of the one that is most abundant, underestimating a possible species richness (RUECKER et al., 2011). However, in our study C. suis, C. hominis, C. parvum and C. baileyi were found in the same sample.

The occurrence of $C$. suis in sewage may occur due to nonhuman sources of fecal material discharged in domestic sewage e.g. slaughterhouse effluents, and rain runoff during rainy seasons, or $C$. suis infection occurs in the human population of the study area. Recent findings suggest that this species may be much more broadly distributed than initially thought (BODAGER et al., 2015). These findings warrant further research on the occurrence of cryptosporidiosis in healthy and immunocompromised individuals. More studies are needed in order to improve our understanding of the epidemiology by $C$. muris and $C$. suis, they are not commonly found in humans but in recent years have gained increased attention (CAMA et al., 2003; LEONI et al., 2006).

C. baileyi causes disease in birds (NAKAMURA \& MEIRELES, 2015). In the present study, the presence of $C$. baileyi in sewage samples may be explained by the fact that there are a large number of synanthropic birds - especially Zenaida auriculata (the eared dove) - in the city of Londrina, PR, Brazil where this survey was carried out. These doves would contaminate the sewage system by runoff as they could shed oocysts in their feces.

C. parvum and C. hominis are the two main species that affect human beings, the former is zoonotic and the latter anthroponotic (RYAN et al., 2014). The presence of $C$. hominis in raw sewage samples indicates the occurrence of cryptosporidiosis in humans in the study area. The presence of $C$. parvum in sewage specimens may suggest the occurrence of an urban zoonotic cycle in this geographic region as this species has also been found in our area in raw water (ALMEIDA et al., 2015). Nevertheless, since $C$. parvum infects a wide range of hosts, we were unable to determine if the oocysts were of human or animal origin. The higher occurrence of $C$. hominis when compared with $C$. parvum corroborates the data on the epidemiology of cryptosporidiosis in Brazil, according to the literature, $C$. hominis infection is more frequently found than C. parvum (ROLANDO et al., 2012).

\section{Conclusion}

The present study documents the occurrence of Giardia and Cryptosporidium species in raw sewage and treated sewage samples from a WWTP located in the city of Londrina, State of Paraná, south Brazil. We demonstrated that $C$. muris is present in treated sewage, and C. muris, C. hominis, C. baileyi, C. suis, and $C$. parvum are present in raw sewage. The presence of $C$. muris, $C$. suis and $C$. baileyi in sewage suggests contamination with feces from rodents, pigs and birds, respectively, or human infection by C. muris and C. suis. C. hominis prevailed over C. parvum in raw sewage samples. Giardia high occurrence frequency confirms the endemic status of this protozoosis in the area.

Our findings highlight the problem of using water bodies that receive effluents from WWTP for human consumption and irrigation. Our study also points out that there is a need for additional research on the characterization and genotyping of species of Cryptosporidium that affect humans in Brazil. Therefore, the role of $C$. suis and $C$. muris in human sporadic cryptosporidiosis should be further investigated.

\section{References}

Almeida JC, Martins FDC, Ferreira JM No, Santos MM, Garcia JL, Navarro IT, et al. Occurrence of Cryptosporidium spp. and Giardia spp. in a public water-treatment system, Paraná, Southern Brazil. Rev Bras Parasitol Vet 2015; 24(3): 303-308. http://dx.doi.org/10.1590/S198429612015051 . PMid:26291147.

Appelbee AJ, Frederick LM, Heitman TL, Olson ME. Prevalence and genotyping of Giardia duodenalis from beef calves in Alberta, Canada. Vet Parasitol 2003; 112(4): 289-294. http://dx.doi.org/10.1016/S03044017(02)00422-3. PMid:12623208.

Araújo AJUS, Kanamura HY, Almeida ME, Gomes AHDS, Pinto THL, Silva AJ. Genotypic identification of Cryptosporidium spp. isolated from HIV-infected patients and immunocompetent children of São Paulo, Brazil. Rev Inst Med Trop São Paulo 2008; 50(3): 139-143. http://dx.doi. org/10.1590/S0036-46652008005000003. PMid:18516466.

Bodager JR, Parsons MB, Wright PC, Rasambainarivo F, Roellig D, Xiao L, et al. Complex epidemiology and zoonotic potential for Cryptosporidium suis in rural Madagascar. Vet Parasitol 2015; 207(1-2): 140-143. http:// dx.doi.org/10.1016/j.vetpar.2014.11.013. PMid:25481280.

Bonatti TR, Franco RMB. Real scale environmental monitoring of zoonotic protozoa and helminth eggs in biosolid samples in Brazil. $J$ Parasit Dis 2016; 40(3): 633-642. http://dx.doi.org/10.1007/s12639014-0549-9. PMid:27605758.

Branco N, Leal DA, Franco RM. A parasitological survey of natural water springs and inhabitants of a tourist city in Southeastern Brazil. Vector Borne Zoonotic Dis 2012; 12(5): 410-417. http://dx.doi.org/10.1089/ vbz.2011.0679. PMid:22217166.

Cama VA, Bern C, Sulaiman IM, Gilman RH, Ticona E, Vivar A, et al. Cryptosporidium species and genotypes in HIV-positive patients in Lima, Peru. J Eukaryot Microbiol 2003;50(Supl. 1): 531-533. http://dx.doi. org/10.1111/j.1550-7408.2003.tb00620.x. PMid:14736153.

Chappell CL, Okhuysen PC, Tzipori S, Widmer G, Lupo PJ, LangerCurry RC. Cryptosporidium muris: infectivity and illness in healthy adult volunteers. Am J Trop Med Hyg 2015; 92(1): 50-55. http://dx.doi. org/10.4269/ajtmh.14-0525. PMid:25311695.

Colli CM, Bezagio RC, Nishi L, Bignotto TS, Ferreira ÉC, FalavignaGuilherme AL, et al. Identical assemblage of Giardia duodenalis in humans, animals and vegetables in an urban area in southern Brazil indicates a relationship among them. PLoS One 2015; 10(3): e0118065. http:// dx.doi.org/10.1371/journal.pone.0118065. PMid:25761119.

Couto MCM, Lima MF, Bomfim TCB. New Cryptosporidium parvum subtypes of IIa subfamily in dairy calves from Brazil. Acta Trop 2014; 130: 117-122. http://dx.doi.org/10.1016/j.actatropica.2013.11.002. PMid:24239750. 
Durigan M, Abreu AG, Zucchi MI, Franco RMB, Souza AP. Genetic diversity of Giardia duodenalis: multilocus genotyping reveals zoonotic potential between clinical and environmental sources in a metropolitan region of Brazil. PLoS One 2014; 9(12): e115489. http://dx.doi. org/10.1371/journal.pone.0115489. PMid:25536055.

Efstratiou A, Ongerth JE, Karanis P. Waterborne transmission of protozoan parasites: review of worldwide outbreaks - An update 2011-2016. Water Res 2017; 114: 14-22. http://dx.doi.org/10.1016/j.watres.2017.01.036. PMid:28214721.

Feng Y, Li N, Duan L, Xiao L. Cryptosporidium genotype and subtype distribution in raw wastewater in Shanghai, China: evidence for possible unique Cryptosporidium hominis transmission. J Clin Microbiol 2009; 47(1): 153-157. http://dx.doi.org/10.1128/JCM.01777-08. PMid:19005143.

Feng Y, Ortega Y, He G, Das P, Xu M, Zhang X, et al. Wide geographic distribution of Cryptosporidium bovis and the deer-like genotype in bovines. Vet Parasitol 2007; 144(1-2): 1-9. http://dx.doi.org/10.1016/j. vetpar.2006.10.001. PMid:17097231.

Feng Y, Ryan UM, Xiao L. Genetic Diversity and population structure of Cryptosporidium. Trends Parasitol 2018; 34(11): 997-1011. http:// dx.doi.org/10.1016/j.pt.2018.07.009. PMid:30108020.

Franco RMB, Branco N, Leal DAG. Parasitologia ambiental: métodos de concentração e detecção de Cryptosporidium spp. e Giardia spp. em amostras de água. Rev Patol Trop 2012; 41(2): 119-135. http://dx.doi. org/10.5216/rpt.v41i2.19320

Franco RMB, Cantusio RC No. Occurrence of cryptosporidial oocysts and Giardia cysts in bottled mineral water commercialized in the City of Campinas, State of São Paulo, Brazil. Mem Inst Oswaldo Cruz 2002; 97(2): 205-207. http://dx.doi.org/10.1590/S0074-02762002000200012. PMid:12016445.

Heiges M, Wang H, Robinson E, Aurrecoechea C, Gao X, Kaluskar N, et al. CryptoDB: a Cryptosporidium bioinformatics resource update. Nucleic Acids Res 2006;34(Suppl 1): 419-422. http://dx.doi.org/10.1093/ nar/gkj078. PMid:16381902.

Hopkins RM, Meloni BP, Groth DM, Wetherall JD, Reynoldson JA, Thompson RC. Ribosomal RNA sequencing reveals differences between the genotypes of Giardia isolates recovered from humans and dogs living in the same locality. J Parasitol 1997; 83(1): 44-51. http://dx.doi. org/10.2307/3284315. PMid:9057695.

Instituto Brasileiro de Geografia e Estatística - IBGE. Cidades, Londrinal $P R$ [online]. Rio de Janeiro: IBGE; 2015 [cited 2017 Oct 12]. Available from: http://cod.ibge.gov.br/233H4

Khouja LBA, Cama V, Xiao L. Parasitic contamination in wastewater and sludge samples in Tunisia using three different detection techniques. Parasitol Res 2010; 107(1): 109-116. http://dx.doi.org/10.1007/s00436010-1844-8. PMid:20352447.

Leoni F, Amar C, Nichols G, Pedraza-Díaz S, McLauchlin J. Genetic analysis of Cryptosporidium from 2414 humans with diarrhoea in England between 1985 and 2000. J Med Microbiol 2006; 55(6): 703-707. http:// dx.doi.org/10.1099/jmm.0.46251-0. PMid:16687587.

Li N, Xiao L, Wang L, Zhao S, Zhao X, Duan L, et al. Molecular surveillance of Cryptosporidium spp., Giardia duodenalis, and Enterocytozoon bieneusi by genotyping and subtyping parasites in wastewater. PLoS Negl Trop Di. 2012; 6(9): e1809. http://dx.doi.org/10.1371/journal.pntd.0001809. PMid:22970334.

Meireles MV. Cryptosporidium infection in Brazil: implications for veterinary medicine and public health. Rev Bras Parasitol Vet 2010; 19(4): 197-204. http://dx.doi.org/10.1590/S1984-29612010000400002. PMid:21184694.
Montemayor M, Valero F, Jofre J, Lucena F. Occurrence of Cryptosporidium spp. oocysts in raw and treated sewage and river water in north-eastern Spain. J Appl Microbiol 2005; 99(6): 1455-1462. http://dx.doi. org/10.1111/j.1365-2672.2005.02737.x. PMid:16313418.

Nakamura AA, Meireles MV. Cryptosporidium infections in birds - a review. Rev Bras Parasitol Vet 2015; 24(3): 253-267. http://dx.doi.org/10.1590/ S1984-29612015063. PMid:26444057.

Nakamura AA, Simões DC, Antunes RG, Silva DC, Meireles MV. Molecular characterization of Cryptosporidium spp. from fecal samples of birds kept in captivity in Brazil. Vet Parasitol 2009; 166(1-2): 47-51. http://dx.doi.org/10.1016/j.vetpar.2009.07.033. PMid:19683397.

Nguyen TT, Traub R, Pham PD, Nguyen HV, Nguyen KC, Phung $\mathrm{CD}$, et al. Prevalence and molecular characterization of Cryptosporidium spp. and Giardia spp. in environmental samples in Hanam province, Vietnam. Food Waterborne Parasitol 2016; 3: 13-20. http://dx.doi. org/10.1016/j.fawpar.2016.03.003.

Plutzer J, Karanis P, Domokos K, Törökné A, Márialigeti K. Detection and characterisation of Giardia and Cryptosporidium in Hungarian raw, surface and sewage water samples by IFT, PCR and sequence analysis of the SSUrRNA and GDH genes. Int J Hyg Environ Health 2008; 211 (5-6): 524-533. http://dx.doi.org/10.1016/j.ijheh.2008.04.004. PMid:18550431

Robertson LJ, Paton CA, Campbell AT, Smith PG, Jackson MH, Gilmour RA, et al. Giardia cysts and Cryptosporidium oocysts at sewage treatment works in Scotland, UK. Water Res 2000; 34(8): 2310-2322. http://dx.doi. org/10.1016/S0043-1354(99)00408-X

Rolando RF, Silva S, Peralta RH, Silva AJ, Cunha FS, Bello AR, et al. Detection and differentiation of Cryptosporidium by real-time polymerase chain reaction in stool samples from patients in Rio de Janeiro, Brazil. Mem Inst Oswaldo Cruz 2012; 107(4): 476-479. http://dx.doi.org/10.1590/ S0074-02762012000400006. PMid:22666857.

Ruecker NJ, Bounsombath N, Wallis P, Ong CSL, Isaac-Renton JL, Neumann NF. Molecular forensic profiling of Cryptosporidium species and genotypes in raw water. Appl Environ Microbiol 2005; 71(12) 8991-8994. http://dx.doi.org/10.1128/AEM.71.12.8991-8994.2005. PMid:16332907.

Ruecker NJ, Hoffman RM, Chalmers RM, Neumann NF. Detection and resolution of Cryptosporidium species and species mixtures by genusspecific nested PCR-restriction fragment length polymorphism analysis, direct sequencing, and cloning. Appl Environ Microbiol 2011; 77(12): 3998-4007. http://dx.doi.org/10.1128/AEM.02706-10. PMid:21498746.

Ryan U, Cacciò SM. Zoonotic potential of Giardia. Int J Parasitol 2013; 43(12-13): 943-956. http://dx.doi.org/10.1016/j.ijpara.2013.06.001. PMid:23856595.

Ryan U, Fayer R, Xiao L. Cryptosporidium species in humans and animals: current understanding and research needs. Parasitology 2014; 141(13): 1667-1685. http://dx.doi.org/10.1017/S0031182014001085. PMid:25111501.

Ryan U, Hijjawi N, Feng Y, Xiao L. Giardia: an under-reported foodborne parasite. Int J Parasitol 2019; 49(1): 1-11. http://dx.doi.org/10.1016/j. ijpara.2018.07.003. PMid:30391227.

Santos LU, Cantusio Neto R, Franco RMB, Guimarães JR. Detecção de oocistos de Cryptosporidium spp. e cistos de Giardia spp. em amostras de esgoto bruto ou tratado: avaliação crítica dos métodos. Eng Sanit Ambient 2011; 16(2): 115-120. http://dx.doi.org/10.1590/S141341522011000200003 . 
Savioli L, Smith H, Thompson A. Giardia and Cryptosporidium join the 'Neglected Diseases Initiative'. Trends Parasitol 2006; 22(5): 203-208. http://dx.doi.org/10.1016/j.pt.2006.02.015. PMid:16545611.

Silva FMP, Lopes RS, Araújo JP Jr. Identification of Cryptosporidium species and genotypes in dairy cattle in Brazil. Rev Bras Parasitol Vet 2013; 22(1): 22-28. http://dx.doi.org/10.1590/S1984-29612013005000010. PMid:23538500.

Silva FMP, Monobe MM, Lopes RS, Araújo JP Jr. Molecular characterization of Giardia duodenalis in dogs from Brazil. Parasitol Res 2012; 110(1): 325334. http://dx.doi.org/10.1007/s00436-011-2492-3. PMid:21695567.

Spanakos G, Biba A, Mavridou A, Karanis P. Occurrence of Cryptosporidium and Giardia in recycled waters used for irrigation and first description of Cryptosporidium parvum and C. muris in Greece. Parasitol Res 2015; 114(5): 1803-1810. http://dx.doi.org/10.1007/s00436-015-4366-6. PMid:25687523.

Thompson RCA, Ash A. Molecular epidemiology of Giardia and Cryptosporidium infections. Infect Genet Evol 2016; 40: 315-323. http:// dx.doi.org/10.1016/j.meegid.2015.09.028. PMid:26458528.

Tiyo R, Souza CZ, Nishi L, Brustolin CF, Ratti BA, Falavigna-Guilherme AL. Water from different sources used for the irrigation of vegetables to be marketed: research on Cryptosporidium spp., Giardia spp., and coliforms in Paraná, Brazil. Rev Inst Med Trop São Paulo 2015; 57(4): 333-336. http://dx.doi.org/10.1590/S0036-46652015000400010. PMid:26422158.

Ulloa-Stanojlović FM, Aguiar BA, Jara LM, Sato MIZ, Guerrero JA, Hachich E, et al. Occurrence of Giardia intestinalis and Cryptosporidium sp. in wastewater samples from São Paulo State, Brazil, and Lima, Peru. Environ Sci Pollut Res Int 2016; 23(21): 22197-22205. http://dx.doi. org/10.1007/s11356-016-7537-9. PMid:27638793.

Vincze T, Posfai J, Roberts RJ. NEBcutter: a program to cleave DNA with restriction enzymes. Nucleic Acids Res 2003; 31(13): 3688-3691. http://dx.doi.org/10.1093/nar/gkg526. PMid:12824395.

Wells B, Shaw H, Hotchkiss E, Gilray J, Ayton R, Green J, et al. Prevalence, species identification and genotyping Cryptosporidium from livestock and deer in a catchment in the Cairngorms with a history of a contaminated public water supply. Parasit Vectors 2015; 8(1): 66. http:// dx.doi.org/10.1186/s13071-015-0684-x. PMid:25650114.

Xiao L, Singh A, Limor J, Graczyk TK, Gradus S, Lal A. Molecular characterization of Cryptosporidium Oocysts in samples of raw surface water and wastewater. Appl Environ Microbiol 2001; 67(3): 1097-1101. http://dx.doi.org/10.1128/AEM.67.3.1097-1101.2001. PMid:11229897.

Xiao S, Hu S, Zhang Y, Zhao X, Pan W. Influence of sewage treatment plant effluent discharge into multipurpose river on its water quality: A quantitative health risk assessment of Cryptosporidium and Giardia. Environ Pollut 2018; 233: 797-805. http://dx.doi.org/10.1016/j. envpol.2017.11.010. PMid:29141237.

Zahedi A, Gofton AW, Jian F, Paparini A, Oskam C, Ball A, et al. Next Generation Sequencing uncovers within-host differences in the genetic diversity of Cryptosporidium gp60 subtypes. Int J Parasitol 2017; 47(10-11): 601-607. http://dx.doi.org/10.1016/j.ijpara.2017.03.003. PMid:28495122. 